\title{
Hydrogen Peroxide and Peracetic Acid Oxidizing Potential in the Treatment of Water
}

\begin{abstract}
ELENA MADALINA POPESCU ${ }^{2 *}$, OCTAV PANTEA ${ }^{1}$, DANIELA GOLOGAN², RAMI DOUKEH ${ }^{1,3}$
'Petroleum- Gas University Ploiesti., 39, Bucharest Blvd., 100680, Ploiesti, Romania

${ }^{2}$ Zonal System Exploitation Prahova, SH Paltinu, 105200, Paltinu, Romania

${ }^{3}$ SC Research Institute For Auxiliary Organics Products SA, ICPAO Medias, 8 Carpati Str., 551022, Medias, Romania

Mixture based on peracetic acid and hydrogen peroxide is a more powerful oxidant than chlorine and chlorine dioxide. The reactivity of this oxidizing mixture with the polluting substances in the water: ammonium compounds, nitrites, iron, manganese, organic proteins is evaluated in this study. The results obtained after tasting this mixture, using various natural groundwater matrices shows an oxidation efficiency of over $90 \%$ of ammonium and nitrite content, between 40-70\% of iron and 25-50\% formanganese forms. The advantage of this oxidation mixture compared to thechlorine substances is that they do not form threehalomethane byproducts that have carcinogenic effect.
\end{abstract}

Keywords: drinking water, hydrogen peroxide, peracetic acid, ammonium removal, underground water oxidation process.

The hydrogen peroxide molecule compared to the water molecule, contains one additional oxygen atom. In the processes of oxidation, the bond between the two oxygen atoms, so-called peroxide bond is broken and there are formed two $\mathrm{OH}$ radicals [1]. These radicals rapidly react with the polluting substances in water: iron, sulfur, manganese, organic proteins, ammonium group compounds. [2] In literature, there are studies on water pollution which is used microorganisms [3,4].

Peracetic acid is a strong and oxidizer acid, and in combination with hydrogen peroxide gives to the mixture stability, high reactivity both on anorganic compounds (dissolved solids, iron, manganese and sulfides) and organic-proteins, organo-ammonia componds, pesticides, gasoline, organic substances and few bacterias, ferobacterias, sulfobacterias groups and Pseudomonas, and $\mathrm{E}$. coli $[5,6]$.

When it's dissolved in water peracetic acid forms hydrogen peroxide and acetic acid. Hydrogen peroxide and peracetic acid are more powerful oxidants than chlorine $\left(\mathrm{Cl}_{2}\right)$, chlorine dioxide $\left(\mathrm{ClO}_{2}\right)$ and potassium permanganate $\left(\mathrm{KMnO}_{4}\right)$. The hydrogen peroxide and peracetic acid oxidation potential is even less than of the ozone.

Table 1

OXIDATION POTENTIAL OF VARIOUS OXIDANTS [1]

\begin{tabular}{|l|l|}
\hline Oxidizing & $\begin{array}{l}\text { Oxidation } \\
\text { potential }\end{array}$ \\
\hline Ozone & 2.1 \\
\hline Peracetic acid & 1.81 \\
\hline Hydrogen peroxide & 1.8 \\
\hline Potassium permanganate & 1.7 \\
\hline Chlorine dioxide & 1.5 \\
\hline Chlorine & 1.0 \\
\hline
\end{tabular}

Hydrogen peroxide oxidation reaction mechanism is based on the release of oxygen free radicals:

$$
\mathrm{H}_{2} \mathrm{O}_{2} \rightarrow \mathrm{H}_{2} \mathrm{O}+2 \mathrm{O}
$$

Oxygen free radicals have both properties of oxidation and disinfection.

The underground waters contain iron and manganese in the reduced form that are $\mathrm{Fe}^{2+}$ and $\mathrm{Mn}^{2+}$, and these compounds have to be oxidized to upper form sand $\mathrm{Mn}^{4+}$ $\mathrm{Fe}^{3+}$ in order to be retained in the filtration step [7].

Depending on the chemical form that exists in the water, the concentration, the presence of other constituents: organic nitrogen compounds, humic acids, these compounds may be oxidized by hydrogen peroxide and peracetic acid [8]

The presence of $C$. perfringens in drinking water can be an indicator of intermittentfecal contamination, that' $s$ why when this thing is detected, the potential contamination sources should be investigated [5].

Compared to Escherichia coli and enterococcistrains, which are less resistant, Clostridium perfringens has the advantage to survive a longer time and that $s$ why it can serve as a fecal pollution indicator, which has previously been and therefore it can indicate the sources of intermittent contamination [1].

Clostridium perfringens is a Gram-positive, anaerobic, sulfite-reducing bacteria, that produces resistant spores to unfavorable conditions in the aquatic environment, including extreme conditions such as: UV radiation, high temperature, acidic or basic $\mathrm{pH}$ and disinfection processes, such as chlorination [9].

Due to the exceptional resistance of $\mathrm{C}$. perfringens spores to desinfection processes and other unfavorable environmental conditions, this bacteria has been proposed as an indicator for enteric viruses and protozoa in drinking water by the WHO (World Health Organization) [10]. The treatment processes designed for removing enteric viruses or protozoa should also eliminate C. perfringens [11].

Its presence in water should lead to a rigurous analysis of all the treatment process parameters, including the desinfection method efficiency.

This microorganism is not a danger into the water, but rather, it is problematic when water comes into contact with food, because it produces exotoxin which causes food poisoning and surgical wounds infections, leading to cangrenade gas [12].

As well as E. coli, C. perfringens does not multiply in the most water environments and it is a highly specific indicator of fecal pollution [13].

In this study there was used an oxidizing mixture, a preparation based on hydrogen peroxide, peracetic acid, acetic acid and water in balance. This product poses a

*email elena_tom06@yahoo.com, Phone: 0762029342 
chemical stability for a relatively long time, over two years and can therefore be used in the treatment process streams. This paper tries to demonstrate the high efficiency of oxidation of the mixture based on hydrogen peroxide and peracetic acid on the content of ammonia, nitrites and the bacteria removal from the underground-water and from the surface water for drinkable purpose [14]. It is also wanted to be demonstrated the product efficacy in the slowdown failure to the removal of the algal blooming increases that can lead to bacterial pathogenic algae increases that produce algae toxins which lead to chronic health effects on consumers [12].

\section{Experimental part}

Materials and methods

The oxidizing mixture was tested by a jar test method.

Jar test method used involved:

- A rapid mixing of $150 \mathrm{rpm}-1$ minute of the raw water without reagent addition

-The mixture adding, different dozes -quickly mixing of $150 \mathrm{rpm}$ - for $3 \mathrm{~min}$

-Slow mixing -40 rpm - for $5 \mathrm{~min}$

- 15 minutes rest

-Supernatant collection

The collected supernatant was tested for: turbidity, ammonia, nitrates, iron, manganese, heterotrophic bacteria, coliforms, E. coli and clostridium perfringens bacteria.[5]

Used analysis methods:

- pH - SR ISO 10523/2012

-permanganate index - SR EN ISO 8467/2001;

- ammonia - SR ISO 7150/2001

-nitrite - SR EN 26777 / 2002c 91/2006

- nitrate-UV absorption at $254 \mathrm{~nm}$

- total-iron SR ISO 6332/96 C 91/2006

-manganese SRENISO 11885

Microbial activity monitoring was carried out by the following methods

\section{The method principle}

Total coliform bacteria and E. coli presence, is emphasized by the 0.45 micron sterile membrane filtration method and by its positioning on Tergitol lactose culture medium which then is incubated at $36^{\circ} \mathrm{C}+/-2^{\circ} \mathrm{C}$ for 21 $+/-3 \mathrm{~h}$. The colonies grown on Tergitol (the presumptive colonies) are subject to the confirmation test for total coliform bacteria oxidase test. The colonies that are oxidase negative reaction to the test are considered to be total coliform bacteria[16].

The result is expressed as the number of colonies / $100 \mathrm{ml}$.Mesophilic bacteria presence is emphasized by seeding the sample using the incorporating method into a solid nutrient medium (nutrient agar) incubated at 37 and $22^{\circ} \mathrm{C}$ for $48 \mathrm{~h}, 72 \mathrm{~h}$ respectively, followed by the developed colonies counting.

The result is expressed as the number of colony forming units per $\mathrm{ml}$ (U.F.C./mL).

Clostridium perfingens is determined by standard method and by this method can be detected vegetative forms, including $\mathrm{C}$. perfingens spores in surface water and in the drinking water. This method consists of 45microns sterile membrane filtration, and then it is transferred into a selective medium and it is incubated under anaerobic conditions at $+44 / \pm 4^{\circ} \mathrm{C}$ for $21 \pm 3 \mathrm{~h}$.

In the experimental program there were conducted $\mathrm{C}$. perfringen tests for each dose of oxidant mixture.

\section{Results and discussions}

The experimental research aimed the mix oxidizing action evaluating on a natural underground fresh water (drilling) sample no. 1 with an ammonium content of 3.62 $\mathrm{mg} / \mathrm{L}$, nitrites content of $0.023 \mathrm{mg} / \mathrm{L}$, nitrates content of $1.76 \mathrm{mg} / \mathrm{L}$, making a treatment with varying amounts of oxidizing mixture between 0.2 and $0.4 \mathrm{ml}$ of an oxidizing mixture per liter of raw water.

The obtained results show a good performance of oxidizing for the mixture mentioned above in oxidation of the ammonium ion in the water with high concentration, the efficiency in reducing the ammonium ion being $100 \%$ (fig. 1).

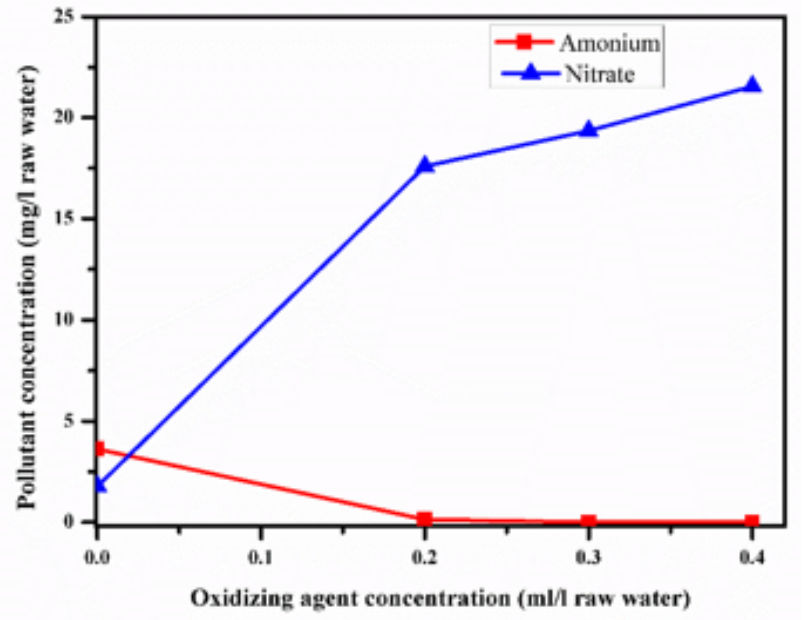

Fig. 1. Oxidant product mix (M.O) action on underground-water with high ammonium content

The oxidation process is complete till the nitrate ion molecules for both simple and organic protein type, and that's why the nitrate ion concentration shows a significant increase.

The of organic substances content significantly decreases by 32 to $64 \%$ depending on the amount of added oxidant mixture.

The following raw water sample, sample no. 2 has an ammonium content of $2.9 \mathrm{mg} / \mathrm{L}$ and the nitrite content of $1.2 \mathrm{mg} / \mathrm{L}$.

The obtained results show a good behavior of the oxidizing mixture upon ammonium ion and nitrite ion in the underground waters (fig 2). The reduction efficiency of the organic substances is between $50-79 \%$.

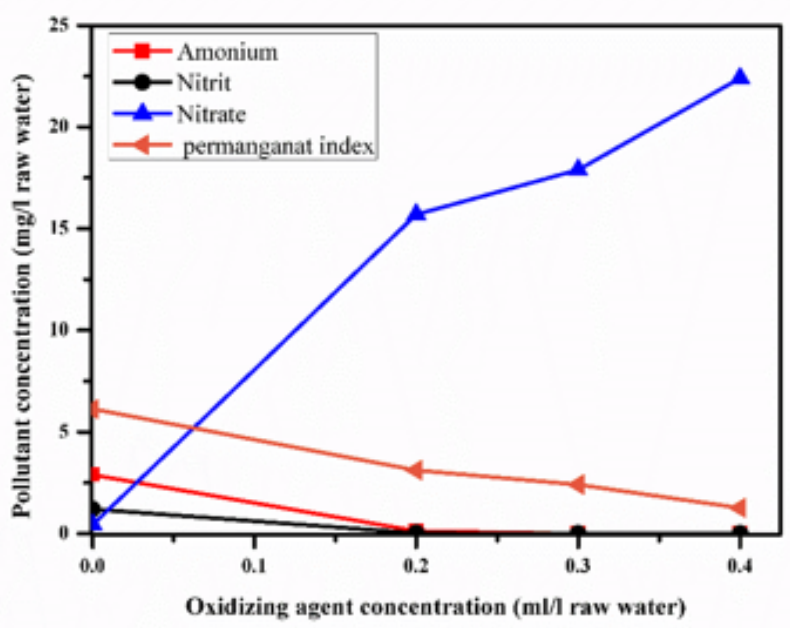

Fig. 2. Oxidant mixture (M.O) action on underground-water containing ammonium and nitrite 
Sample no. 3 has an iron content of $0.42 \mathrm{mg} / \mathrm{L}$, and the manganese content of $0.08 \mathrm{mg} / \mathrm{L}$. For these waters the oxidant mixture evaluation was carried out after the filtering step through quartz sand with a grain size from 1 to $2 \mathrm{~mm}$, because the iron and manganese ions after their oxidation are retained by the filtration step.

The obtained results show a good efficiency of the oxidant mixture in reducing the content of ammonia, iron and manganese in the underground water, the efficiency of ammonia reduction being $100 \%$, the efficiency of iron oxidation is $72 \%$ and that of manganese by $50 \%$ (fig. 3 and 4).

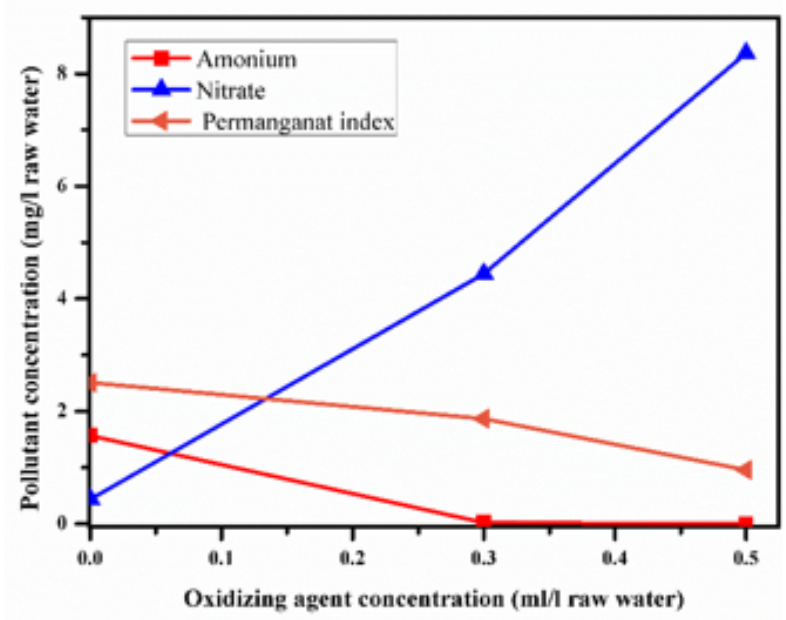

Fig. 3. Oxidant mixture (M.O) action on underground-water containing ammonium, iron and manganese

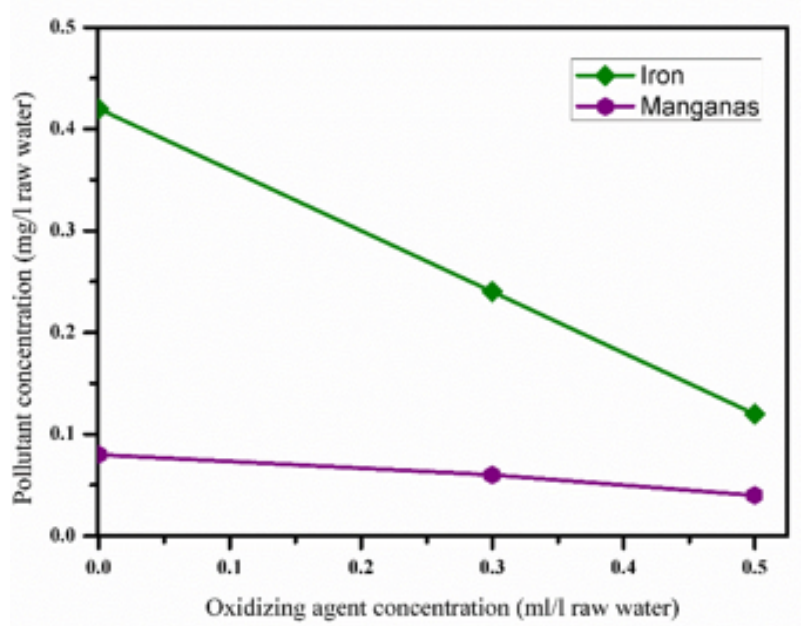

Fig. 4. Oxidant mixture (M.O) action on underground-water containing ammonium, iron and manganese

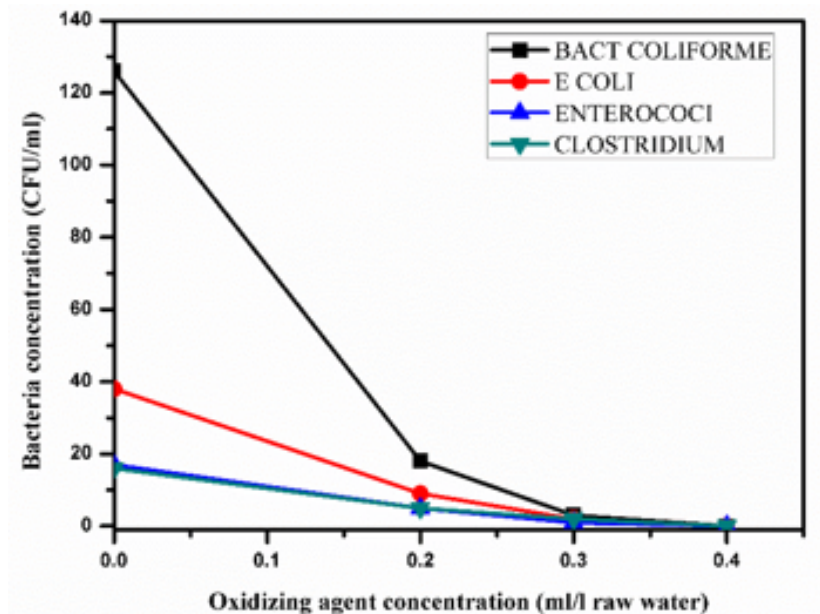

Fig.5. Oxidizing mixture action on underground-water containing Coliform bacteria, E.coli, Enterococci and Clostridium

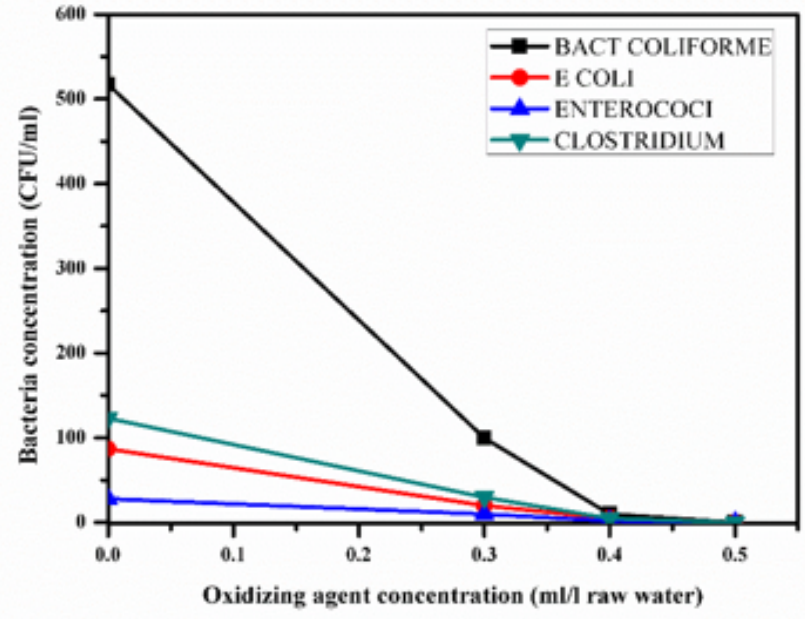

Fig.6. Oxidizing mixture action on underground-water containing Coliform bacteria, E.coli, Enterococci and Clostridium

Samples 2 had an initial charge of 126 CFU / mL Coliform, 38 CFU / mL E. coli, 17 CFU / mL Enterococci, 16UFC / $\mathrm{mL}$ Clostridium perfingens. Sample 3had 517 CFU / mL Coliform, 87 CFU / mL E. coli, 28CFU / mL Enterococci and $123 \mathrm{CFU} / \mathrm{mL}$ Clostridium Perfingen. The results show a reduction of about five times of the studied ferobacteria.

\section{Conclusions}

The objective of this experimental program was to assess the performance of the oxidizing mixture based on hydrogen peroxide and peracetic acid on the organic, bacteriological and chemical load in the underground raw water and in the surface water. Therefore there were chosen different doses of mixture for testing, according to the load of the water.

After the done tests there was concluded that this product is efficient inwater treatment oxidation processes for obtaining drinking water and industrial for ammonium, nitrates, iron, manganese, organic substances with large chain reduction such as:

- it reduce with an efficiency of $100 \%$ the ammonium content, at doses of $0.2-0.3 \mathrm{ml} / \mathrm{L}$ raw water with a high content of ammonium and nitrite.

- oxidize the iron forms betw een $40-70 \%$, depending on the product dose.

- oxidize manganese forms with an efficiency between $25-50 \%$, depending on the product

dose.

The advantage of the oxidizing mixture based on hydrogen peroxide and peracetic acid is that it doesn't form carcinogenic residual compounds such as the chlorinated compounds.

It has oxidizing and disinfectant effect on bacteria and algae, limiting biofilm formation in the water treatment systems.

\section{References}

1.*** www.lenntech.com/processes/disinfection/chemical.

2.CRITTENDEN, J. C., TRUSSELL, R., MWH's Water Treatment: Principles and Design, Third Edition, 2012 cap 6-9.

3. LUPU,F., GHEORGHE, C. G., PANTEA, O., CALIN, C., Biotreatment of the Oil Pollutants,Rev. Chim. (Bucharest), 64, no. 2, 2013 p.210. 4.NICOLESCU, F., LUPU, F., PANTEA, 0., GHEORGHE, C. G., BONDAREV, A., CALIN, C., Toxicity Study of Benzene, Toluene and Xylene (BTX) at Exposure on Some Experimental Groups, Rev. Chim. (Bucharest), 66, no. 8, 2015 p.1181.

5.SIBECHE, G.,Cercetãri bacteriologice, serologice si de patogenitate privind prezena speciei Clostridium Perfringens în alimente de origine animalã, teza doctorat, 2009, USAMV-lasi 
6.NIEMINSKI E. C., Removing Giardia and Cryptosporidium by Conventional Treatment and Direct Filtration, J ournal AWWA, 1995, 87 (9): 96 ,.

7.***Norma de calitate pe care trebuie sa le îndeplineascã apele de suprafata utilizate pentru potabilizare, NTPA 013.

8.***https://en.wikipedia.org/wiki/Clostridium_perfringens.

9.GOLOGAN, D., POIENARIU, G., The bio-film-its implications in the technological process of producing drinking water and its reduction, ERPUB International Conference Sept. 4-5, 2015, Istanbul, Turkey. 10.*** Guidelines for Drinking-water Quality-OMS-2011
11.*** USEPA - Optimizing Water Treatment Plant Performance Using the Composite Correction Program. EPA/625/6-91/027, Center for Environmental Research Information, Cincinnati, 1998.

12.GOLOGAN, D., RACOVITEANU, G., Biofloculanpi - o alternativa pentru înlocuirea poliacrilamidei în tratarea apelor de suprafata supuse potabilizarii, Romaqua nr. 5/2013, vol. 89, ISSN 1453-6986.

13.GOLOGAN, D., Influena proceselor de coagulare asupra biostabilitãii apei, teza doctorat, 2014, UTCB Bucuresti

14.FIGUERAS,M. J., BORREGO, J., New Perspectives in Monitoring Drinking Water Microbial Quality, Int. J. Environ. Res. Public Health 2010, 7, 4179-4202.

$\overline{\text { Manuscript received: } 19.06 .2018}$ 